\title{
AS INFLUÊNCIAS GLOBAIS, NACIONAIS E LOCAIS NA CRIAÇÃO DE UMA POLITICA AMBIENTAL: O SISTEMA MUNICIPAL DE UNIDADES DE CONSERVAÇÃO DA NATUREZA (SMUP) EM RECIFE, PERNAMBUCO
}

\author{
GLOBAL, NATIONAL AND LOCAL INFLUENCES IN THE CREATION OF AN \\ ENVIRONMENTAL POLICY: THE MUNICIPAL SYSTEM OF NATURE CONSERVATION \\ UNITS (SMUP) IN RECIFE, PERNAMBUCO
}

Andreia Patrícia dos SANTOS ${ }^{1}$, Cristiano Wellington Noberto RAMALHO².

Artigo recebido em 27/04/2020, aceito em 27/05/2020, publicado em 30/06/2020.

\begin{abstract}
RESUMO
Palavras-chave:

Unidades de

conservação da

natureza; SMUP;

Campo político;

Política pública

ambiental.

O presente trabalho encontra-se inserido no debate sobre Política Pública Ambiental, compreendida como uma ação do campo político planejada com determinado fim. Dentro disso, encontra-se o Sistema Municipal de Unidades Protegidas da Cidade do Recife, 0 SMUP, que regula a criação e a elaboração dos Planos de Manejos de 25 Unidades de Conservação da Natureza (UCN) situadas na capital pernambucana (Recife). O período de análise vai de 1986 a 2014, intervalo entre a primeira política ambiental implantada em Recife até a criação do SMUP. Sob o ponto de vista teórico, a análise sustentou-se no debate sobre Política Pública, a partir da discussão de Pierre Muller e Yves Surel, e de Campo Político, com base na teoria de Pierre Bourdieu. Podemos concluir que o SMUP, enquanto política pública ambiental, é resultado de pressões nacionais e internacionais e, também, do campo político local com suas pautas e disputas.
\end{abstract}

Keywords:

Nature conservation

units; SMUP;

Political field;

Environmental public policy.

\section{A B S T R A C T}

The present work is part of the debate on Environmental Public Policy, understood as an action in the political field planned with a specific purpose. As part of this policy, there is the Municipal System of Protected Units of the City of Recife, the SMUP, which regulates the creation of the Management Plans of 25 Nature Conservation Units (UCN) in the capital of Pernambuco (Recife). The analysis period of time is from 1986 to 2014, from the first environmental policy implemented in Recife until the creation of SMUP. From the theoretical point of view, the analysis was sustained in the debate on Public Policy, based on the discussion of Pierre Muller and Yves Surel, and on the Political Field, based on the theory of Pierre Bourdieu. We can conclude that SMUP, as an environmental public policy, is the result of national and international pressures and, also, of the local political field with its agendas and disputes.

\footnotetext{
1 Bolsista FACEPE/Departamento de Sociologia da UFPE/PPGS. E-mail: andreiasantos25@gmail.com. ORCID: https://orcid.org/0000-0003-2714-1113.

2 Professor do Departamento de Sociologia (DS) e do Programa de Pós-graduação em Sociologia (PPGS) da UFPE. É pesquisador do Núcleo de Estudos Humanidades, Mares e Rios (Nuhumar)/UFPE e do CNPq (bolsista PQ2). E-mail: cristiano.ramalho@yahoo.com.br. ORCID: http://orcid.org/0000-0002-1648-456X.
} 


\section{INTRODUÇÃO}

Não é novidade que o debate sobre o Meio Ambiente tem como um de seus marcos a Conferência de Estocolmo realizada em $1972^{3}$ e que foi organizada pelas Nações Unidas (ONU). Ela, também, foi importante ao tornar o debate ambiental em uma questão cada vez mais globalizada, especialmente alguns temas que são hoje ainda atuais, como o das mudanças climáticas.

Tal Conferência deu origem não apenas a outros encontros que emergiram na mesma linha, que começaram a influenciar as agendas de políticas públicas em vários países. Contudo, o grande impacto deuse em abril de 1987, a partir da Comissão Brundtland, quando esta publica o relatório intitulado "Nosso Futuro Comum", fazendo, daí em diante, do conceito Desenvolvimento Sustentável um elemento importante nos debates públicos que compuseram um conjunto de iniciativas anteriores a Agenda 21 que nasce no Rio-924. Anos depois, em 2015, a ONU lançou a Agenda 2030, que trouxe 17 Objetivos de Desenvolvimento Sustentável (ODS), resultado de um esforço coletivo, universal. Estes objetivos estão voltados para a proteção dos recursos naturais em escala global e para promover o desenvolvimento sustentável desses recursos e da sociedade, apontando, em primeira mão, para a erradicação da pobreza no mundo. Essa agenda reforçou e apontou, de modo mais incisivo, para uma universalização de questões, fortemente relacionadas desde o Relatório de Brundtland, a ineliminável complementariedade entre elementos da ordem econômica, social e ambiental. Se existe universalidade nas questões ambientais anteriormente frisadas, há peculiaridades locais (biológicas, históricas, culturais, sociais e econômicas) que devem ser consideradas, quando pensamos nos problemas relacionados ao meio ambiente e na sua gestão em um contexto de um País periférico, principalmente em uma de suas regiões mais desiguais, como é o caso do Nordeste em que se situa Recife.

Dentro das várias áreas que envolvem o tema do meio ambiente, enquanto interesse da gestão pública, uma das formas adotadas pelos estados e municípios no Brasil - de maior repercussão - foi a criação de Sistemas de Unidades Protegidas ou de Unidades de Conservação, que passou a adotar como referência de legislação o Sistema Nacional de Unidades de Conservação, o SNUC, criado pelo Governo Federal em 18 de julho de 2000, por meio da Lei 9.985, com o objetivo de assegurar a criação, implantação e gestão de unidades de conservação (UCs) no País ${ }^{5}$. Aliás, a ideia de proteção da natureza, através da escolha de

\footnotetext{
${ }^{3}$ Antes da Conferência, 1968, foi criado o Clube de Roma, que tratou de questões internacionais relacionadas ao Meio Ambiente, no entanto, só passou a ter seu trabalho reconhecido mundialmente em 1972, momento também que participou na Conferência das Nações Unidas em Estocolmo.

${ }^{4}$ A Agenda 21 surge na Conferência das Nações Unidas sobre Meio Ambiente e Desenvolvimento (CNUMAD), na cidade do Rio de Janeiro, Brasil, em 1992. Seu objetivo foi traçar diretrizes direcionadas para os problemas prementes da atualidade, visando, também, preparar o mundo para os desafios do próximo século.

${ }^{5}$ Não estamos afirmando que não havia políticas para a constituição de unidades de proteção da natureza anteriormente no Brasil, pois algumas áreas protegidas emergem desde a década de 1930 (DIEGUES, 2004).
} 
determinados lugares possuidores de riqueza ecológica (fauna e flora), foi algo também que emergiu no plano internacional e que foi incorporada ao longo do planeta por inúmeras nações, sendo postulada e defendida também pelos encontros da ONU.

A reflexão sobre as problemáticas globais acerca do Meio Ambiente permite indagações relevantes para pensarmos como se processa (e processou) no plano local as políticas públicas vinculadas à temática ambiental em Recife, Pernambuco, particularmente sobre as Unidades de Conservações. Nesse sentido, algumas perguntas são centrais: de que maneira as questões globais são (e foram) reproduzidas na realidade local? como pensar as questões ambientais locais a partir das pressões externas e globais? de que modo a política ambiental adotada em âmbito local pode contribuir ou dialogar com esse debate global, de alguma maneira? É com base nessas questões que almejamos pensar a temática ambiental no Recife, a saber, a presente análise almeja focalizar o Sistema de Unidades Protegidas, SMUP, da cidade do Recife, em Pernambuco, criado em 2014 e que hoje é responsável pela existência de 25 Unidades de Conservação da Natureza (UCNs). Essas Unidades destacam-se por uma particularidade, que é o fato de todas localizarem-se no perímetro urbano da cidade, sendo, portanto, áreas com alta densidade populacional em seu entorno.

Com a finalidade de tornar a discussão mais clara, vale frisar que a mesma parte do histórico da criação de Leis instituídas entre os anos de 1986 e 2014 em Pernambuco. O período escolhido se deve pela seguinte razão: em 1986 foi o ano no qual o governo do estado de Pernambuco publicou a primeira Lei para a proteção ambiental, que incluiu UCNs localizadas em Recife; e 0 ano de 2014 foi o período que se publicou 0 SMUP, que previu a elaboração dos respectivos planos de manejos dessas Unidades. A metodologia aplicada baseou-se, além da leitura de escritos acadêmicos (artigos e livros), na análise de documentos (leis federais, estaduais e municipais), que resultaram em políticas públicas para o Meio Ambiente, sendo o SMUP uma expressão dessa política no Recife. Sob o ponto de vista teórico, o conceito utilizado é o de Políticas Públicas, caracterizada por uma ação pública, sendo também um dos resultados das pressões externas ao campo político (movimentos sociais, cientistas, organismos internacionais como a ONU, entre outros) que interagem com o poder público (MULLER; SUREL, 2002).

Para Muller (2002):

Uma política pública é formada, inicialmente, por um conjunto de medidas concretas que constituem a substância "visível" da política. Esta substância pode ser constituída de recursos: financeiros (os créditos atribuídos aos ministérios), intelectuais (a competência que os atores das políticas são capazes de mobilizar), reguladores (o fato de elaborar uma nova regulamentação constitui um recurso novo para os tomadores de decisão), materiais. Ela é também constituída de "produtos", isto é, de outputs reguladores (normativos), financeiros, físicos (MULLER, 2002, p. 13, grifos do autor).

Quanto à noção de Campo Político, a mesma tem sustentação na teoria de Pierre Bourdieu, e a partir dela é que as discussões do Meio Ambiente e da Unidade de Conservação da Natureza serão incorporadas, 
estando elas presentes, ao nosso ver, no SMUP. Para tratar do conceito de campo político, primeiro é fundamental destacar o que Pierre Bourdieu definiu como campo:

Um campo é um campo de forças, e um campo de lutas para transformar as relações de forças. Em um campo como o campo político ou o campo religioso, ou qualquer outro campo, as condutas dos agentes são determinadas por sua posição na estrutura da relação de forças característica desse campo no momento considerado (BOURDIEU, 2011, p. 201).

Sob essa perspectiva teórica de Pierre Bourdieu, ele, o campo político, é um campo de forças entre os agentes que se encontram dentro do mesmo espaço social, utilizando-se de estratégias para dominar 0 campo e/ou mesmo disputar capitais simbólicos que os distingue dos seus pares, tendo a capacidade de concretizar ações. É nesse contexto que consideramos que a política pública é realizada (BOURDIEU, 2004).

Para dar conta da discussão proposta o texto traz um resgate sobre as ações globais sobre o meio ambiente e também a inserção do Brasil em tal cenário. A partir daí é que entraremos nas políticas públicas locais destinadas à temática ambiental e, portanto, o próprio SMUP.

\section{Meio Ambiente: um debate globalizado}

A discussão sobre a proteção dos recursos naturais é relativamente recente, tem pouco mais de 40 anos. Entretanto, ela vem ao longo desses anos ampliando seu foco em virtude do alto nível de prejuízos causados ao Meio Ambiente em escala global devido à ideia de progresso, aos modelos de desenvolvimento, modos de vida moderno e à expansão de uma cultura consumista. Essas ações estão no centro dessa problemática, sendo somente a ponta do iceberg, pois outros determinantes mais robustos sustentaram $\mathrm{e}$ ainda sustentam o uso exacerbado dos recursos naturais. Isso pode ser interpretado à luz do debate da expansão do capitalismo e o consequente avanço da indústria, especialmente após a Segunda Guerra Mundial, fatores esses que provocaram grandes mudanças na nossa história, por exemplo: sociais, econômicas, ambientais e científicos, entre outros. O desenvolvimento científico e tecnológico aliado à ideia de desenvolvimento econômico propagou a utilização de combustíveis fósseis e seus subprodutos gasosos (petróleo, gás natural e carvão) entre outros, que, se por um lado, trouxeram benefícios para a humanidade, por outro, levaram a poluição atmosférica e a degradação ambiental (SILVA, 2009). Portanto, dentro dessa conjuntura, fica evidente que as questões relacionadas ao Meio Ambiente são de natureza multi e interdisciplinar, complexas, conectadas e cada vez mais universalizadas.

O mencionado tema ganhou, ao longo das últimas décadas, grande relevância, devido aos impactos negativos ocasionados pela falta de preservação/conservação dos recursos naturais. Movimentos sociais de Defesa do Meio Ambiente, estudiosos e organismos internacionais, especialmente a ONU, aderiram à ideia de discutir 0 assunto em escala global, através da definição de uma agenda sobre o tema. 0 marco foi a 
Conferência das Nações Unidas sobre o Meio Ambiente Humano realizada em 1972 em Estocolmo ${ }^{6}$, capital da Suécia, na qual participaram 113 países. Foi a primeira vez que o Meio Ambiente foi discutido e considerado uma questão de interesse mundial. Vale mencionar que a discussão sobre o Meio Ambiente, antes mesmo da Conferência, já tinha sido considerada pela ONU. Assim: "o problema ambiental como decorrente de externalidades econômicas próprias do excesso de desenvolvimento (tecnologia agressiva e consumo excessivo), de um lado, e de sua falta (crescimento demográfico e baixo PIB per capita), de outro" (NASCIMENTO, 2012, p. 53). Nesses termos a dimensão social passou a ser incorporada no debate ambiental, deixando de ser restrito aos recursos naturais e as interferências do desenvolvimento econômico (Idem, 2012).

Em 1987 a Comissão Mundial sobre Meio Ambiente e Desenvolvimento das Nações Unidas (CNUMAD) publicou o Relatório de Brundtland, ficou conhecido como "nosso futuro comum" e difundiu o conceito "desenvolvimento sustentável" (IPIRANGA, GODOY, BRUNSTEIN, 2011), que hoje é largamente utilizado entre estudiosos das questões ambientais (pesquisas científicas) e o Poder Público (políticas públicas/ações públicas).

Vinte anos depois após da Conferência de Estocolmo foi realizada a segunda CNUMAD no Brasil, cidade do Rio de Janeiro e ficou conhecida como ECO 92. Um dos seus resultados foi a Agenda 21 Global durante a Conferência, a qual adotou o conceito de desenvolvimento sustentável, que passou a ser o norteador das ações relacionadas entre desenvolvimento e meio ambiente. Também foi elaborada a Agenda 21 Brasileira, elaborada a partir da Agenda global, que foi um "instrumento de planejamento participativo para o desenvolvimento sustentável do país, resultado de uma vasta consulta à população brasileira [...] e entregue à sociedade, por fim, em 2002" (MMA, 2002)7. Por essa razão as questões ambientais é parte de uma agenda universal, o que justificou o tema ser amplamente abordado nessas duas importantes Conferências internacionais (a de Estocolmo, em 1972 e a ECO 92 no Rio de Janeiro). Além dessas, foi realizada na África do Sul, na cidade de Johannesburgo em 2002, conhecida como Rio+10 ou Cúpula Mundial sobre Desenvolvimento Sustentável, tendo como objetivo:

O objetivo principal da Conferência seria rever as metas propostas pela Agenda $21 \mathrm{e}$ direcionar as realizações às áreas que requerem um esforço adicional para sua implementação, assim como refletir sobre outros acordos e tratados da Rio-92. Essa nova Conferência Mundial levaria à definição de um plano de ação global, capaz de conciliar as necessidades legítimas de desenvolvimento econômico e social da humanidade, com a obrigação de manter o planeta habitável para as gerações futuras (SENIQUEL, 2002, p. 02).

\footnotetext{
6 É relevante mencionar que "em 1982 foi convocada a Conferência de Nairóbi, para fazer um balanço da atuação do PNUMA e da implementação do Plano de Ação de Estocolmo. Em parte essa conferência também prestava contas às organizações não governamentais (ONGs) e às lideranças ambientalistas". No entanto, "o resultado desse balanço não foi muito animador. Constatouse que ambientalmente o mundo estava pior do que em 1972 (quando da Conferência de Estocolmo), e que o Plano de Ação praticamente não saíra do papel" (NETO, 2010, p. 64).

${ }^{7}$ Informações em https://www.mma.gov.br/responsabilidade-socioambiental/agenda-21. Acesso em 13/4/2020.
} 
Nesse sentido, outras ações relacionadas com o Meio Ambiente foram empreendidas inseridas no debate sobre a proteção do Meio Ambiente em nível global, são eles: o Protocolo de Montreal em 1987 e, 10 anos depois, o Protocolo de Kyoto. O de Montreal visou:

[...] substituir as substâncias que demonstraram reagir quimicamente com o ozônio na parte superior da estratosfera, as Substâncias Destruidoras da Camada de Ozônio (SDOs), como os grupos Clorofluocarbonos (CFCs), Halons, Tetracloretos de Carbono (CTCs) e Hidroclorofluorcarbono (HCFCs), emitidas em todo o globo, a partir dos processos de industrialização. Entrou em vigor em 1/1/1989 e sofreu emendas nas reuniões de Londres (1990), Copenhague (1992), Viena (1995), Montreal (1997) e Pequim (1999) (SILVA, 2009, p.156).

A proposta de substituição dessas substâncias danosas à natureza em escala global foi uma ação inovadora, de extrema importância para o combate ao aquecimento global 8 que trouxe, entre outras consequências, sérias mudanças climáticas ${ }^{9}$ no planeta. Nessa mesma direção, o Protocolo de Kyoto10foi fruto das metas instituídas durante a ECO 92, que estabeleceu "metas de redução de emissão de gases de efeito estufa e mecanismos adicionais de implementação para que estas metas sejam atingidas" (MOREIRA; GIOMETTI, 2008, p. 10). Assim, o Protocolo foi implantando e:

[...] foi aberto para assinatura em 16 de março de 1998. Entrará em vigor 90 dias após a sua ratificação por pelo menos 55 Partes da Convenção, incluindo os países desenvolvidos que contabilizaram pelo menos 55\% das emissões totais de dióxido de carbono em 1990 desse grupo de países industrializados. Enquanto isso, as Partes da Convenção sobre Mudança do Clima continuarão a observar os compromissos assumidos sob a Convenção e a preparar-se para a futura implementação do Protocolo (MCT, 1998, p.02).

Além disso, o Protocolo de Kyoto foi um importante passo para a discussão internacional relativa às mudanças climáticas globais, embora a ONU já tivesse promovido em 1979 a Primeira Conferência Mundial sobre o Clima em Genebra, na Suiça, mas, em virtude da intensificação dos gases de efeito estufa no planeta, isso se evidenciou como algo mais premente. Por isso, o Protocolo trouxe a seguinte consideração:

[...] a temperatura da Terra pode levar a eventos climáticos cada vez mais extremos, como recorde da amplitude das ondas, derretimento de geleiras, aumento do nível do mar, alteração no suprimento de água doce, maior número de ciclones, tempestades cada vez mais destrutivas e freqüentes enchentes, secas cada vez mais intensas, rápido ressecamento dos solos, extinção de algumas espécies de plantas e animais, entre outros (MOREIRA; GIOMETTI, 2008, p. 12).

\footnotetext{
8 Para Neto (2010, p. 38) o aquecimento global pode ser compreendido a partir da seguinte definição: "Por aquecimento global entende-se a elevação da temperatura média da Terra. Algumas de suas causas possíveis são o efeito estufa e o aumento da atividade solar. $\mathrm{O}$ aquecimento global pode gerar epidemias de doenças tropicais, afetar os padrões das chuvas e o equilíbrio entre as estações do ano. Dentre outros impactos, pode afetar o próprio clima da Terra".

${ }^{9}$ De acordo com Neto (2010, p. 38) definiu Mudanças climáticas como: "alterações no sistema climático terrestre, que podem advir do aquecimento global, de alterações na circulação oceânica ou de outros fatores. O conceito de mudanças climáticas, central para este estudo, será retomado e aprofundado mais adiante".

$10 \mathrm{http}: / /$ mudancasclimaticas.cptec.inpe.br/ rmclima/pdfs/Protocolo_Quioto.pdf
} 
Sobre as Mudanças Climáticas Globais, nove anos depois da Primeira Conferência em 1979 sobre este tema, a ONU criou o Painel Intergovernamental de Mudanças Climáticas em 1988, para divulgação de pesquisas científicas sobre o assunto. Em 1990 foi realizada a Segunda Conferência do Clima, momento no qual os cientistas reavaliaram as decisões tomadas em 1979, considerando as novas pesquisas sobre 0 aquecimento global. Já em 1995 ocorreu o Mandato de Berlim ou a COP1 (Conferência das Partes) com a finalidade de reforçar a responsabilidade dos países para reversão das mudanças do clima no mundo (Idem, 2008; SANTOS, 2017).

Dando prosseguimento a esse breve levantamento das questões ambientais no centro do debate mundial, é relevante destacar que, também, foi realizada a $21^{\text {a }}$ Conferência das Partes (COP-21) das Nações Unidas sobre Mudança do Clima no período de 30 de novembro a 11 de dezembro de 2015 ocorrida em Paris, França, com a finalidade de "alcançar um novo acordo internacional sobre o clima, aplicável a todos os países, com o objetivo de manter o aquecimento global abaixo dos $2^{\circ} \mathrm{C}$ " (COP-21, 2015) $)^{11}$. É fundamental mencionar que essa foi uma decisão tomada pela Convenção - Quadro das Nações Unidas sobre Mudança do Clima (UNFCCC) no Rio de Janeiro durante a ECO 92. Então, a COP-21 pode ser assim entendida: "Convenção-Quadro é uma convenção universal de princípios, reconhecendo a existência de mudanças climáticas antropogênicas - ou seja, de origem humana - e dando os países industrializados a maior parte da responsabilidade para combatê-la" (Idem, 2015). Como desdobramento desse conjunto de ações, assinou-se o Acordo de Paris, que entrou em vigor em 2016, substituindo o Protocolo de Kyoto.

Conforme acima relatado, o Meio Ambiente passou a ser debatido dentro de uma perspectiva globalizada, tendo em vista a importância e conservação dos recursos naturais como elemento central para a qualidade da vida da população mundial e a garantia desses para as gerações futuras. Foi a partir daí que os eventos promovidos pela ONU destacaram-se por ser, além de espaços formuladores de caminhos, arenas políticas de debates, embates e disputas entre países e de demandas das sociedade civil organizada (Ong's, movimentos sociais) em relação aos poderes públicos acerca da agenda ambiental a ser construída e seguida em termos globais, como exemplos podemos lembrar dos posicionamentos do governo norteamericano, especialmente de seu presidente Donald Trump, sobre as mudanças climáticas nas reuniões da ONU. Então, tais encontros podem ser definidos como um campo político com suas lutas, tensões, posições, acúmulos de capital e de poder simbólico.

Poder simbólico este no sentido empregado por Bourdieu (2004, p. 185), que o definiu como "lugar de uma concorrência pelo poder que se faz por intermédio de uma concorrência pelos profanos ou, melhor, pelo monopólio do direito de falar e de agir em nome de uma parte ou da totalidade dos profanos". E é sob essa perspectiva que os agentes do campo político posicionam-se nas lutas ocorridas no interior do campo, porque

\footnotetext{
11 Informações disponíveis em: https://nacoesunidas.org/cop21/. Acesso em 16 abr. 18.
} 
"há, no campo político, lutas simbólicas nas quais os adversários dispõem de armas desiguais, de capitais desiguais, de poderes simbólicos desiguais" (BOURDIEU, 2011, p. 204). Isto é, países como a França, a Inglaterra, os Estados Unidos, a China, a Alemanha, etc. possuem poderes e capitais simbólicos capazes de interferir em decisões e/ou de influenciar no que concerne aos encontros do Meio Ambiente da ONU e seus encaminhamentos, que outras nações em desenvolvimento não detêm.

É dentro dessa perspectiva que o Brasil inseriu-se no debate, isto é, como resultado da pressão dos organismos internacionais, mesmo que iniciativas e instrumentos jurídicos de proteção à natureza tenham antecedido a esse movimento mais global, mas o que já existia era insuficiente. Também havia demandas oriundas do nascente movimento ambientalista no País, embora vivêssemos em plena ditadura militar (19641985) com reações contrárias a agenda ambiental (DIEGUES, 2004; BURSZTYN; BURSZTYN, 2013).

\section{A inserção do Brasil no debate ambiental}

Em termos de Política Pública para o Meio Ambiente no Brasil, consideramos como referência a Política Nacional do Meio Ambiente (PNMA) concretizada através da Lei $n^{0} 6.938$ datada de 31 de agosto de 1981, 9 anos depois da Conferência de Estocolmo, que visou "a preservação, melhoria e recuperação da qualidade ambiental propícia à vida, visando assegurar, no País, condições ao desenvolvimento socioeconômico, aos interesses da segurança nacional e à proteção da dignidade da vida humana". 0 tema também foi incluído na Constituição Federal de 1988 no artigo 225, que estabeleceu: "todos têm direito ao meio ambiente ecologicamente equilibrado, bem de uso comum do povo e essencial à sadia qualidade de vida, impondo-se ao poder público e à coletividade o dever de defendê-lo e preservá-lo para as presentes e futuras gerações". É importante frisar que mesmo antes da PNMA foram publicadas importantes Leis para a proteção do meio ambiente, a exemplo da Lei do Patrimônio Cultural em 1937 e do primeiro Código Florestal em 1965. Essas e outras Leis anteriores à PNMA são importantes marcos regulatórios para a preservação dos recursos naturais em nível nacional, além de inúmeros decretos com a mesma finalidade. No entanto, muitas outras surgiram mediante às demandas e pressões externas, especialmente a partir da intervenção da ONU em 1972.

Abaixo, segundo o Quadro 01, é apresentado um panorama da Política Pública Ambiental implementada no Brasil com destaque para as Leis sancionadas pelo Governo Federal no período de 1937 a 2012: 
Quadro 01 - Políticas Públicas Ambientais no Brasil (1937 a 2012)

\begin{tabular}{|c|c|c|}
\hline ANO & LEI/DECRETO & OBJETO \\
\hline 1937 & $\begin{array}{c}\text { Lei Patrimônio Cultural } \\
\text { NN}^{0} 25 \text { de } 30 / 11 / 1937\end{array}$ & $\begin{array}{l}\text { Proteção do Patrimônio Histórico e Artístico Nacional (bens de valor } \\
\text { etnográfico, arqueológico, os monumentos naturais, além dos sítios e } \\
\text { paisagens de valor notável pela natureza }\end{array}$ \\
\hline 1967 & $\begin{array}{l}\text { Lei da Fauna Silvestre } \\
\text { No } 5.197 \text { de } \\
03 / 01 / 1967 .\end{array}$ & $\begin{array}{l}\text { Classifica como crime o uso, perseguição, apanha de animais silvestres, } \\
\text { caça profissional, comércio de espécies da fauna silvestre e produtos } \\
\text { derivados de sua caça, além de proibir a introdução de espécie exótica e a } \\
\text { caça amadorística sem autorização do IBAMA. }\end{array}$ \\
\hline 1965 & $\begin{array}{l}\text { Lei das Florestas - } \\
\text { Código Florestal } 4.771 \\
\text { de } 15 / 09 / 1965 .\end{array}$ & $\begin{array}{l}\text { Determinou a proteção de florestas nativas e define como áreas de } \\
\text { preservação permanente (onde a conservação da vegetação é obrigatória) } \\
\text { uma faixa de } 30 \text { a } 500 \text { metros nas margens dos rios, de lagos e de } \\
\text { reservatórios, além de topos de morro, encostas com declividade superior } \\
\text { a } 45 \text { graus e locais acima de } 1.800 \text { metros de altitude. }\end{array}$ \\
\hline 1977 & $\begin{array}{c}\text { Lei das Atividades } \\
\text { Nucleares } N^{0} 6.453 \text { de } \\
17 / 10 / 1977 . \\
\end{array}$ & $\begin{array}{l}\text { Dispõe sobre a responsabilidade civil por danos nucleares e a } \\
\text { responsabilidade criminal por atos relacionados com as atividades } \\
\text { nucleares. }\end{array}$ \\
\hline 1979 & $\begin{array}{l}\text { Lei do Parcelamento } \\
\text { do Solo Urbano }-\mathrm{N}^{\circ} \\
6.766 \text { de } 19 / 12 / 1979 . \\
\end{array}$ & $\begin{array}{l}\text { Estabelece as regras para loteamentos urbanos, proibidos em áreas de } \\
\text { preservação ecológicas, naquelas onde a poluição representa perigo à } \\
\text { saúde e em terrenos alagadiços }\end{array}$ \\
\hline 1980 & $\begin{array}{l}\text { Lei do Zoneamento } \\
\text { Industrial nas Áreas } \\
\text { Críticas de Poluição } \\
\quad N^{0} 6.803 \text { de } \\
\quad 02 / 07 / 1980 \text {. }\end{array}$ & $\begin{array}{l}\text { Atribui aos estados e municípios o poder de estabelecer limites e padrões } \\
\text { ambientais para a instalação e licenciamento das indústrias, exigindo o } \\
\text { Estudo de Impacto Ambiental. }\end{array}$ \\
\hline 1981 & $\begin{array}{l}\text { Política Nacional de } \\
\text { Meio Ambiente Lei No } \\
6.938 / 90 \text { de } \\
31 / 08 / 1981\end{array}$ & $\begin{array}{l}\text { É a lei ambiental mais importante e define que o poluidor é obrigado a } \\
\text { indenizar danos ambientais que causar, independentemente da culpa, a } \\
\text { obrigatoriedade dos estudos e respectivos relatórios de Impacto Ambiental } \\
\text { (EIA-RIMA) e o Conselho Nacional de Meio Ambiente (CONAMA). }\end{array}$ \\
\hline 1985 & $\begin{array}{c}\text { Lei da Ação Civil } \\
\text { Pública }-\mathrm{N}^{0} 7.347 \text { de } \\
24 / 07 / 1985 . \\
\end{array}$ & $\begin{array}{l}\text { Lei de interesses difusos. Trata da ação civil publica de responsabilidades } \\
\text { por danos causados ao meio ambiente, ao consumidor e ao patrimônio } \\
\text { artístico, turístico ou paisagístico. }\end{array}$ \\
\hline 1988 & $\begin{array}{l}\text { Lei do Gerenciamento } \\
\text { Costeiro }-\mathrm{N}^{0} 7.661 \mathrm{de} \\
16 / 05 / 1988\end{array}$ & $\begin{array}{l}\text { Define as diretrizes para criar o Plano Nacional de Gerenciamento } \\
\text { Costeiro, ou seja, define o que é zona costeira como espaço geográfico da } \\
\text { interação do ar, do mar e da terra, incluindo os recursos naturais e } \\
\text { abrangendo uma faixa marítima e outra terrestre. }\end{array}$ \\
\hline \multirow[t]{3}{*}{1989} & $\begin{array}{l}\text { Lei da criação do } \\
\text { IBAMA - N } 7.735 \text { de } \\
22 / 02 / 1989 .\end{array}$ & $\begin{array}{l}\text { Criou o Ibama, incorporando a Secretaria Especial do Meio Ambiente e as } \\
\text { agências federais na área de pesca, desenvolvimento florestal e borracha. } \\
\text { Compete executar a política nacional do meio ambiente: conservar, } \\
\text { fiscalizar, controlar e fomentar o uso racional dos recursos naturais. }\end{array}$ \\
\hline & $\begin{array}{l}\text { Lei dos Agrotóxicos - } \\
\text { № } 7.802 \text { de } \\
10 / 07 / 1989 .\end{array}$ & $\begin{array}{l}\text { Dispõe sobre pesquisa, experimentação, produção, embalagem e } \\
\text { rotulagem, transporte, armazenamento, comercialização, propaganda } \\
\text { comercial, utilização, importação, exportação, destino final dos resíduos e } \\
\text { embalagens, registro, classificação, controle, inspeção e fiscalização de } \\
\text { agrotóxicos, seus componentes e afins. }\end{array}$ \\
\hline & $\begin{array}{c}\text { Lei } n^{0} 7.797 \text {, de } 10 / 07 / \\
1989 .\end{array}$ & Cria o Fundo Nacional de Meio Ambiente (FNMA) \\
\hline 1991 & $\begin{array}{c}\text { Lei da Política Agrícola } \\
-\mathrm{N}^{0} 8.171 \text { de } \\
17 / 01 / 1991 \\
\end{array}$ & $\begin{array}{l}\text { A proteção do meio ambiente está entre seus objetivos e um de seus } \\
\text { instrumentos. Define que o poder público deve disciplinar e fiscalizar o uso } \\
\text { racional do solo, da água, da fauna e da flora. }\end{array}$ \\
\hline 1995 & $\begin{array}{l}\text { Lei da Engenharia } \\
\text { Genética - N }{ }^{0} 8.974\end{array}$ & $\begin{array}{l}\text { Estabelece normas para aplicação da engenharia genética, desde o } \\
\text { cultivo, manipulação e transporte de organismos modificados (OGM), até }\end{array}$ \\
\hline
\end{tabular}




\begin{tabular}{|c|c|c|}
\hline & de 05/01/1995. & sua comercialização, consumo e liberação no meio ambiente. \\
\hline 1997 & $\begin{array}{l}\text { Lei de Recursos } \\
\text { Hídricos - No } 9.433 \text { de } \\
08 / 01 / 1997\end{array}$ & $\begin{array}{l}\text { Institui a Política Nacional de Recursos Hídricos e cria o Sistema Nacional } \\
\text { de Recursos Hídricos. Define a água como recurso natural limitado, dotado } \\
\text { de valor econômico e de usos múltiplos. }\end{array}$ \\
\hline 1998 & $\begin{array}{l}\text { Lei de Crimes } \\
\text { Ambientais }-N^{0} 9.605 \\
\text { de } 12 / 02 / 1998\end{array}$ & $\begin{array}{l}\text { Reordena a legislação ambiental brasileira no que se refere às infrações e } \\
\text { punições. A pessoa jurídica, autora ou co-autora da infração ambiental, } \\
\text { pode ser penalizada, chegando à liquidação da empresa, se ela tiver sido } \\
\text { criada ou usada para facilitar ou ocultar um crime ambiental. }\end{array}$ \\
\hline 1999 & $\begin{array}{l}\text { PNEA - Lei No } 9.795 \\
\text { de } 27 / 04 / 1999 .\end{array}$ & $\begin{array}{l}\text { Dispõe sobre a educação ambiental, institui a Política Nacional de } \\
\text { Educação Ambiental. }\end{array}$ \\
\hline \multirow[t]{3}{*}{2000} & $\begin{array}{l}\text { Lei № 10.165, de } \\
27 / 12 / 2000 \text {. }\end{array}$ & $\begin{array}{l}\text { Altera a Lei no 6.938, de } 31 \text { de agosto de } 1981 \text {, que dispõe sobre a } \\
\text { Política Nacional do Meio Ambiente, seus fins e mecanismos de } \\
\text { formulação e aplicação, e dá outras providências. }\end{array}$ \\
\hline & $\begin{array}{l}\text { Lei No } 9.984 \text {, de } \\
17 / 07 / 2000\end{array}$ & $\begin{array}{l}\text { Criação da Agência Nacional de Água - ANA, entidade federal de } \\
\text { implementação da Política Nacional de Recursos Hídricos. }\end{array}$ \\
\hline & $\begin{array}{c}\text { Lei No } 9.985, \text { de } \\
18 / 07 / 2000 \\
\end{array}$ & $\begin{array}{l}\text { Institui o Sistema Nacional de Unidades de Conservação da Natureza } \\
\text { (SNUC). }\end{array}$ \\
\hline 2005 & $\begin{array}{l}\text { Organismos } \\
\text { Geneticamente } \\
\text { Modificados (OGM) } \\
\text { Lei N }{ }^{0} 11.105 \text {, de } \\
\text { 24/03/2005 }\end{array}$ & $\begin{array}{l}\text { Estabelece normas de segurança e mecanismos de fiscalização sobre } \\
\text { construção, cultivo, produção, manipulação, transporte, transferência, } \\
\text { importação, exportação, armazenamento, pesquisa, comercialização, } \\
\text { consumo, liberação no meio ambiente e descarte de organismos } \\
\text { geneticamente modificados e seus derivados e observância para a } \\
\text { proteção do meio ambiente. }\end{array}$ \\
\hline 2006 & $\begin{array}{l}\text { Lei da Mata Atlântica } \\
N^{0} 11.428 \text {, de } \\
22 / 12 / 2006\end{array}$ & $\begin{array}{l}\text { Dispõe sobre a utilização e proteção da vegetação nativa do Bioma Mata } \\
\text { Atlântica, isto é, formações florestais nativas e ecossistemas associados. }\end{array}$ \\
\hline 2006 & $\begin{array}{l}\text { FNDF - Lei No } 11.284 \\
\text { de } 02 / 03 / 2006\end{array}$ & $\begin{array}{l}\text { Dispõe sobre a gestão de florestas públicas para a produção sustentável; } \\
\text { institui, na estrutura do Ministério do Meio Ambiente, o Serviço Florestal } \\
\text { Brasileiro - SFB; cria o Fundo Nacional de Desenvolvimento Florestal - } \\
\text { FNDF. }\end{array}$ \\
\hline \multirow[t]{2}{*}{2007} & $\begin{array}{l}\text { PNPCT - Decreto No } \\
6.040 \text { de } 07 / 02 / 2007\end{array}$ & $\begin{array}{l}\text { Fica instituída a Política Nacional de Desenvolvimento Sustentável dos } \\
\text { Povos e Comunidades Tradicionais - PNPCT, na forma do Anexo a este } \\
\text { decreto que instituiu a Política Nacional de Desenvolvimento Sustentável } \\
\text { dos Povos das Comunidades Tradicionais. }\end{array}$ \\
\hline & $\begin{array}{l}\text { Criação do ICMBIO } \\
\text { Lei No } 11.516 \\
28 / 08 / 2007\end{array}$ & $\begin{array}{l}\text { Fica criado o Instituto Chico Mendes de Conservação da Biodiversidade - } \\
\text { Instituto Chico Mendes (ICMBIO), vinculada ao Ministério do Meio } \\
\text { Ambiente }\end{array}$ \\
\hline 2010 & $\begin{array}{l}\text { Política Nacional de } \\
\text { Resíduos Sólidos - Lei } \\
n^{0} 12.305 \text { de } \\
02 / 08 / 2010 .\end{array}$ & $\begin{array}{l}\text { Dispõe sobre seus princípios, objetivos e instrumentos, bem como sobre } \\
\text { as diretrizes relativas à gestão integrada e ao gerenciamento de resíduos } \\
\text { sólidos, incluídos os perigosos, às responsabilidades dos geradores e do } \\
\text { poder público e aos instrumentos econômicos aplicáveis. }\end{array}$ \\
\hline 2011 & $\begin{array}{l}\text { Licenciamento } \\
\text { Ambiental } \\
\text { Lei complementar } n^{0} \\
140, \text { de } 08 / 12 / 2011\end{array}$ & $\begin{array}{l}\text { Fornece diretrizes para a descentralização da gestão, de forma qualificada } \\
\text { e com transparência de informações, resultando em última análise na } \\
\text { manutenção da capacidade de suporte e melhor conservação do meio } \\
\text { ambiente natural. }\end{array}$ \\
\hline 2012 & $\begin{array}{l}\text { Novo Código Florestal } \\
\text { Lei } 12.651 \text { de } \\
\text { 25/05/2012. Alterado } \\
\text { pela Lei } n^{0} 12.727 \text {, de } \\
17 / 10 / 2012\end{array}$ & $\begin{array}{l}\text { Dispõe sobre a proteção da vegetação nativa. Esta Lei estabelece normas } \\
\text { gerais sobre a proteção da vegetação, áreas de Preservação Permanente } \\
\text { e as áreas de Reserva Legal. }\end{array}$ \\
\hline
\end{tabular}

Fonte: Ministério do Meio Ambiente. Organização dos autores. 
Conforme o quadro acima instituíram-se 28 Leis no período de 1937 a 2012, destacadas por suas finalidades, todas relacionadas, de algum modo, ao meio ambiente, incluindo aquelas que tratam dos mais diversos recursos naturais, além da criação de órgãos governamentais de proteção ambiental, o IBAMA (1989) e o ICMBIO (2007). Esses dispositivos foram, sem dúvida, significativos para a Política Ambiental no Brasil, já que traziam contribuições para iniciativas posteriores estimuladas pela ONU. Dessa maneira, outro documento aprovado, juntamente com a Agenda 21 Brasileira, anteriormente aludida, foi a Convenção sobre a Diversidade Biológica (CDB), que expressou avanços para as ações da Política Ambiental. Sobre isso CARREGOSA; SILVA; KUNHAVALIK, (2015, p. 309) frisou:

[...] tem como pressuposto essencial a compatibilização entre a proteção dos recursos biológicos e o desenvolvimento econômico e social. Assim, visando ao cumprimento dos compromissos assumidos junto à convenção, o governo brasileiro criou, em 1994, o Programa Nacional da Diversidade Biológica (PRONAABIO), instituiu, em 2000, o Sistema Nacional de Unidades de Conservação (SNUC), em 2002, a Política Nacional da Biodiversidade (PNB) (Brasil, 2002) e em 2003 criou a Comissão Nacional da Biodiversidade (CONABIO) (Brasil, 2003).

A CDB foi um passo essencial na Política Ambiental em território brasileiro, dando origem a outros instrumentos legais fundamentais como o PRONABIO, o SNUC, a PNB e a Comissão Nacional da Biodiversidade (CONABIO), tendo diversos representantes em sua estrutura, entre os quais órgãos do governo e entidades da sociedade civil, e como finalidade "identificar e propor áreas e ações prioritárias para a pesquisa, a conservação e o uso sustentável dos componentes da biodiversidade" (Idem, 2015, p. 309), sendo esse um espaço, um campo político com recorte ambiental, que permitiu a participação social ao ter entre seus membros representantes de organizações da sociedade civil (associações de moradores, movimentos sociais, entre outros).

Nessa perspectiva, cabe destacar a instauração da Lei 9.985/2000 em âmbito nacional, que criou 0 Sistema Nacional de Unidades de Conservação (SNUC), definiu as áreas como espaços territoriais e seus recursos ambientais, incluindo as águas jurisdicionais, com características naturais relevantes, legalmente instituídas pelo Poder Público com objetivos e limites definidos, sob regimes especiais de administração e com garantias de proteção (BRASIL, 2000). Essa Lei introduziu modificações importantes na política de criação e gestão de Unidade de Conservação no País, contribuindo para a superação de equívocos cometidos no processo histórico de implantação dessas áreas protegidas, que era centrado na criação de Unidades de caráter restritivo à ocupação humana. Essa prática ocorreu em detrimento de experiências que pudessem incluir as comunidades da área e do entorno em sua gestão, a partir do reconhecimento de sua identidade, da legitimação de seu saber e do investimento na melhoria de suas condições de vida (Idem, 2000). 
Então, o SNUC oficializou o tema do desenvolvimento sustentável como uma alternativa possível para os "problemas" causados pela ocupação humana em UCs, que são muitas vezes habitadas por populações tradicionais (pescadores, indígenas, camponeses, quilombolas, entre outros) e definiu essas Unidades "como o espaço territorial e seus recursos ambientais, incluindo as águas jurisdicionais, com características naturais relevantes, legalmente instituído pelo Poder Público", objetivando a "conservação e limites definidos, sob regime especial de administração, ao qual se aplicam garantias de proteção" (SNUC, 2012).

Dessa maneira, o SNUC determinou as UCs em dois grupos: 1) Unidades de Proteção Integral (uso indireto dos recursos naturais: estação ecológica, reserva biológica, parque nacional, refúgio de vida silvestre e monumento natural) e 2) Unidades de Uso Sustentável (uso sustentável e conservação da natureza: área de proteção ambiental, área de relevante interesse ecológico, floresta nacional, reserva extrativista, reserva da fauna, reserva de desenvolvimento sustentável e reserva particular do patrimônio natural) (ICMBIO, 2018). Para a primeira categoria, a UC tem regras mais restritivas, possibilitando apenas o uso indireto dos recursos naturais (recreação em contato com a natureza, turismo ecológico, pesquisa científica, educação e interpretação ambiental, etc.). Para as de uso sustentável, as atividades permitidas são aquelas atividades humanas que não prejudiquem as dinâmicas ecológicas.

O SNUC, além de incorporar, introduziu valiosos instrumentos jurídicos na política de criação e gestão de UCs no Brasil, que também contribuiu significativamente para a das definições dos conceitos e estabelecimento das normas ao longo da história de implantação dessas áreas, seguindo uma corrente preservacionista12 $^{12}$ capitaneado pelo IBAMA (CARREGOSA; SILVA; KUNHAVALIK, 2015), em que pese avanços a partir de elementos conservacionistas presentes nesta lei. Assim, "essa prática ocorreu em detrimento de experiências que pudessem incluir as comunidades da área e do entorno em sua gestão e conservação, a partir do reconhecimento de sua identidade", isto é, "da legitimação de seu saber e do investimento na melhoria de suas condições de vida" (Idem, 2015, p. 307). Vale salientar que os saberes e fazeres produzidos pelas populações e comunidades tradicionais é o conhecimento tradicional que "pode ser definido como o saber e o saber-fazer - a respeito do mundo natural, sobrenatural - gerados no âmbito da sociedade não-urbano/industrial, transmitidos, em geral, oralmente de geração em geração". Dessa maneira, [...] "para muitas dessas sociedades, sobretudo as indígenas, existe uma interligação orgânica entre o mundo natural, o sobrenatural e a organização social" (DIEGUES, 2004, p. 14). No tocante à essa discussão, é expressivo mencionar a criação do Instituto Chico Mendes de Conservação da Biodiversidade - Instituto Chico Mendes, o ICMBIO, que é:

[...] responsável pela execução das ações da política nacional das unidades de conservação, cabendo ao Instituto, dentre outras atribuições, executar as políticas de uso

\footnotetext{
12 De acordo com Diegues (2004, p.10) "no início do século, os cientistas passaram a exercer uma importância cada vez maior na definição das áreas protegidas, sobressaindo-se os cientistas naturais, uma vez que, segundo a visão predominante, se tratava de proteger o mundo natural contra a ação humana."
} 
sustentável dos recursos naturais renováveis e de apoio ao extrativismo e às populações tradicionais nas unidades de conservação federais de uso sustentável (Brasil, 2007).

Dessa maneira, tanto a criação do ICMBIO como também a Política Nacional de Desenvolvimento Sustentável dos Povos e Comunidades Tradicionais (PNDSPCT), ambas publicadas no ano de 2007, buscaram promover a valorização das comunidades tradicionais mediante ações sustentadas nos instrumentos jurídicos e passou a ser o órgão executor das políticas públicas ambientais, principalmente para as populações tradicionais residentes (ou que estão no entorno) das Unidades de Conservação de uso sustentável. De acordo com o SNUC (2000 p. 07), Unidade de Conservação é um:

Espaço territorial e seus recursos ambientais, incluindo as águas jurisdicionais, com características naturais relevantes, legalmente instituído pelo Poder Público, com objetivos de conservação e limites definidos, sob regime especial de administração, ao qual se aplicam garantias adequadas de proteção.

O SNUC foi o ponto de partida, a referência legal para que os governos estaduais e municipais passassem a criar seus sistemas de Unidades de Conservação, a saber, o SNUC foi decisivo para que os poderes públicos estaduais e municipais passassem a implementar uma Política Ambiental em suas respectivas instâncias. Conforme dados do Ministério do Meio Ambiente (MMA) ${ }^{13}$, hoje são 399 unidades estaduais e 229 unidades municipais de proteção integral, e as UCs de uso sustentável somam 653 unidades estaduais e 161 unidades municipais espalhadas no País.

É dentro desse contexto que encontram-se inseridas as 25 Unidades de Conservação da Natureza (UCN) de Recife e o Sistema Municipal de Unidades Protegidas (SMUP).

\section{Política Ambiental em Pernambuco: breve histórico}

O marco da Política Pública Ambiental em Pernambuco situação na implantação de Leis estaduais para a proteção dos diversos ecossistemas existentes no estado, são elas: lei de proteção às áreas estuarinas, proteção das orlas marítimas, reservas ecológicas e sistemas de parques. Dentre essas áreas protegidas por Lei, estão aquelas localizadas na capital do estado (Recife). Nessa perspectiva, é de grande valia trazer o conceito de Política Ambiental, que pode ser compreendida enquanto:

Conjuntos de iniciativas governamentais coordenadas, envolvendo diferentes organismos e setores de intervenção pública, em articulação com atores não governamentais e produtivos, voltados à proteção, conservação, uso sustentável e recomposição dos recursos ambientais. 0 foco não é apenas o ambiente biofísico, mas também o modo como as populações as atividades produtivas interagem com os diferentes ecossistemas. 0 ambiente construído, que inclui cidades e infraestruturas em geral, também faz parte do escopo das políticas ambientais (BURSZTYN; BURSZTYN, 2013, p. 182).

13 Informações disponíveis nos dados consolidados do MMA, atualizados em 28/01/2020: https://www.mma.gov.br/images/arquivo/80229/CNUC_FEV20\%20-\%20B_Cat.pdf. Acesso em 15 abr.2020. 
A Política Ambiental possibilita não apenas a proteção dos recursos naturais, mas particularmente, "0 ambiente construído, que inclui cidades e infraestruturas em geral, também faz parte do escopo das políticas ambientais", e as UCNs da cidade de Recife estão situadas no centro urbano e podem ser visualizadas por este prisma, pois a interação entre a natureza e a sociedade está fortemente imbricada, não podendo ser dissociadas, mas encontrar um caminho para que essa relação seja possível. Isso só pode ser pensado e aplicado se houver políticas públicas efetivas de proteção da natureza e, na mesma medida, para as pessoas. Nesse contexto, é significativo trazer também o conceito adotado pelos autores acima referidos sobre as questões ambientais:

[...] inclui e transcende os elementos do mundo natural, como a fauna, a flora, a atmosfera, o solo, os recursos hídricos. Engloba, também, as relações entre as pessoas e meio onde vivem. Portanto, tratar a questão ambiental demanda conhecimentos sobre o meio físico e bioético e a dimensão socioeconômica e cultural, tudo isso circunscrito a um dado contexto político-institucional, onde aqueles aspectos interagem (Idem, 2013, p. 42).

Dessa maneira, importa saber que as Políticas Públicas Ambientais precisam incorporar a dimensão social na elaboração de seus instrumentos de gestão como é o caso dos Planos de Manejo das 25 UCNs estabelecido pelo SMUP, pois as questões ambientais "engloba, também, as relações entre as pessoas e meio onde vivem". Assim, o Meio Ambiente é um debate interdisciplinar, pois demanda "conhecimentos sobre o meio físico e bioético e a dimensão socioeconômica e cultural", é, portanto, sob esse o prisma que as PPM devem direcionar suas ações. Em conjunto com essas questões e as influenciando nessa mesma época, 0 tema ambiental passou a fazer parte dos debates públicos da sociedade recifense, pernambucana, através da ação de intelectuais vinculados à academia (Fundação Joaquim Nabuco - FUNDAJ -, Universidade Federal de Pernambuco - UFPE - e Universidade Federal Rural de Pernambuco - UFRPE), bem como do nascente movimento ambientalista e de Organizações Não Governamentais (ONG's) que colocaram a agenda da natureza como algo relevante para o planejamento de políticas públicas (NEGREIROS, 2008; 2018). Tudo isso mostra que a questão do Meio Ambiente passou a constituir-se em um campo político de embates, de ideias, disputas, autoridades, definição de critérios e de consolidação de ações objetivas em Recife.

Sob essa reflexão, abaixo segue um histórico das Políticas Públicas Ambientais instituídas em Pernambuco com foco para a capital nas áreas localizadas na cidade do Recife:

\section{Lei $n^{0} 9.931$ de 11 de dezembro de 1986 - Proteção de Áreas Estuarinas'14:}

Sob o ponto de vista dos estuários foram definidas as reservas biológicas como áreas de proteção ambiental, que são aquelas situadas no litoral do Estado de Pernambuco, formadas pelas seguintes áreas

\footnotetext{
$14 \mathrm{http}: / /$ legis.alepe.pe.gov.br/texto.aspx?id=4853\&tipo=TEXTOORIGINAL
} 
estuarinas: área estuarina dos Rios Goiana e Megaó; área estuarina do Rio Itapessoca; área estuarina do Rio Jaguaribe; área estuarina do Canal de Santa Cruz; área estuarina do Rio Timbó; área estuarina do Rio Paratibe; área estuarina do Rio Beberibe (situado em Recife); área estuarina do Rio Capibaribe (situado em Recife); área estuarina dos Rios Jaboatão e Pirapama; área estuarina dos Rios Sirinhaém e Maracaípe; área estuarina do Rio Formoso; área estuarina do Rio Carro Quebrado; e a área estuarina do Rio Una. A Lei destacou também a situação particular de duas áreas que estão localizadas no meio urbano para que as condições de utilização sejam delimitadas, definida com base em planos específicos, isto é, plano de manejo, a serem elaborados para cada uma delas, as áreas estuarinas do Rio Paratibe, Rio Beberibe e Rio Capibaribe.

Nunca é demais lembrar que a presente lei emergiu num contexto de cobranças sociopolíticas fortes dos movimentos sociais e da sociedade como um todo, pois as usinas lançavam suas caldas nos rios pernambucanos, alcançando o rio Capibaribe que deságua em Recife. A forte poluição (também ocasionado por outras indústrias), o mal cheiro e a intensa mortandade de pescados fez-se ver e sentir nas águas e bairros do Recife, além de vários municípios da Região Metropolitana da capital pernambucana e de municípios situados na área da zona da mata do estado. Por conta disso, grandes passeatas ocorreram em Recife, cobrando dos gestores públicas medidas contra tal questão (CALLOU, 1986; RAMALHO; SANTOS, 2020), o que mostra que a preocupação em relação à gestão da natureza passou a ser incorporada pelos debates do campo político, fato que também tem a ver com a lei que destacaremos abaixo.

\section{Lei $n^{0} 9.960$ de 17 de dezembro de 1986 - Proteção da Orla Marítima:}

Esta foi direcionada para a Proteção da Orla Marítima e estabeleceu regras para aquelas áreas que eram/são consideradas de "Interesse Especial para fins do Controle do Uso do Solo e sua compatibilização com a Preservação do Patrimônio Natural e Paisagístico, nos termos da Lei Federal $n^{0}$ 6.766, de 19 de dezembro de 1979, as faixas de Orla Marítima do Estado de Pernambuco", (ALEPE, 2018). Foram as seguintes: Orla Marítima do Município de Goiana; Orla Marítima do Município de Ipojuca; Orla Marítima do Município de Sirinhaém; Orla Marítima do Município de Rio Formoso; Orla Marítima do Município de Barreiros e Orla Marítima do Município de São José da Coroa Grande. A Orla de Boa Viagem em Recife não foi incluída na mencionada Lei. 


\section{Lei $n^{0} 9.989$ de 13 de janeiro de 1987 - Reservas Ecológicas na Região}

O Governo do estado instituiu a Lei ${ }^{0} 9989$ de 13/01/1987, na qual ficaram definidas 40 Reservas na região metropolitana do Recife, desse total 6 estão situadas na capital do estado, entre elas, Dois Irmãos (passou a ser Parque em 1998), Jardim Botânico, Jardim Uchôa, Dois Unidos, Curado e São João da Várzea.

De acordo com a Lei, em seu primeiro artigo ficou definida "como reservas ecológicas as áreas de preservação permanente da Região Metropolitana do Recife e dispõe sobre procedimentos básicos relativos à sua preservação". Sobre as Reservas Ecológicas da Região Metropolitana do Recife, o Artigo $2^{\circ}$, elas foram definidas "para fins de proteção do sistema hidrográfico, do relevo, do solo, da fauna e da flora existentes, as áreas de preservação permanente". Nessas circunstâncias, as referidas Reservas Ecológicas na Região Metropolitana do Recife foram assim classificadas: 8 no município de Itamaracá: Lanço dos Cações; Santa Cruz; Jaguaribe; Eng. Macaxeira; Eng. São João; Amparo. Em Igarassu foi incluída a Usina São José e 2 em Abreu e Lima: Miritiba e São Bento. Na cidade do Paulista, foram incluídas 3: Jaquarana; Caetés e Janga e em Olinda a Mata de Passarinho. Na capital, foram incluídas nessa categoria 6 reservas acima citadas. Quanto ao município de São Lourenço da Mata, foram inclusas 6 áreas de mata: Quizanga, Tapacurá, Eng. Tapacurá, Toré, Camucim e Outeiro do Pedro. Em Jaboatão dos Guararapes: Jangadinha, Mussaiba, Manassu e Eng. Salgadinho. No município de Moreno, entraram as seguintes reservas: Engenho Moreninho e Caraúna e no Cabo de Santo Agostinho, Contra-Açude, Sistema Gurjaú, nos Municípios do Moreno, Cabo e Jaboatão, Bom Jardim, Serra Cumaru, Serra do Cotovelo, nos Municípios do Cabo e Moreno, Urucu, Camaçari, Duas Lagoas e Zumbi. Além da proteção dessas áreas também ficou estabelecido o Sistema de Parques Metropolitanos também em 1987.

Todas elas têm como características o fato de serem unidades de proteção integral, cuja presença humana é vista como um problema. Em larga medida, tal opção revela algumas importantes questões: (a) uma forte influência que havia no plano internacional imposta pelas correntes preservacionistas desde 0 surgimento das UC's, ramificando-se de setores da academia (biólogos) para a tecnocracia e também se apresentava nos movimentos ambientalistas; e os encontros e algumas diretrizes da ONU não escaparam dessa influência; e (b) Recife e o estado, como um todo, não ficou incólume a essas influências, suas tensões e encaminhamentos, o que resplandeceu nas ações do campo político que optaram, com base nos capitais acumulados e seus poderes simbólicos, numa supremacia das questões mais preservacionistas.

Nesse contexto, cabe destacar a criação do Sistema Estadual de Unidades de Conservação - SEUC, instituído sob a Lei n 13.787 datada de 08 de junho de 2009 no âmbito do Estado de Pernambuco. A definição de Unidade de Conservação (UC) ou Unidade de Conservação da Natureza (UCN) no SEUC seguiu a do SNUC, que determinou critérios e normas para a criação, implantação e gestão das Unidades de Conservação nos estados. Em seu $3^{\circ}$ artigo, a Lei estabeleceu que o SEUC "é constituído pelas unidades de 
conservação instituídas nas esferas estadual e municipal". Desse modo, o referido sistema "deverá abranger toda a diversidade de ecossistemas naturais existentes no território pernambucano e nas suas águas jurisdicionais". É oportuno dizer que, no SEUC, não está previsto, por lei, a criação de Reservas Extrativistas, mostrando a forte presença, também em âmbito local, das correntes preservacionistas em suas definições e a força ainda limitada dos conservacionistas (MORAIS, 2020) na disputa deste campo político. De acordo com a Agência Estadual de Meio Ambiente, a $\mathrm{CPRH}^{15}$, órgão responsável pela administração e gestão ambiental das Unidades de Conservação (UCs) estaduais, existem em Pernambuco 81 Unidades de Conservação Estaduais (40 de Proteção Integral e 41 de Uso Sustentável).

Desse total, foram incluídas 7 Unidades que são áreas sobrepostas, isto é, a gestão dessas UCNs é do estado e em parte responsabilidade do município de Recife, capital do estado, que são: APA AldeiaBeberibe, Reserva de Floresta Urbana Mata de Dois Unidos, Parque Estadual Dois Irmãos, Refúgio de Vida Silvestre Mata do Curado, Refúgio de Vida Silvestre Mata do São João da Várzea, Refúgio de Vida Silvestre Mata do Engenho Uchôa (essas são consideradas reservas ecológicas) e APA Estuarina do Rio Capibaribe (proteção de orla marinha). Essas Reservas Ecológicas, a APA Estuarina e outras 18 novas áreas foram consideradas a partir da Lei de Uso e Ocupação do Solo, LUOS, n 16.176 de 1996, passando a ser denominadas de Zona Especial de Proteção Ambiental (ZEPA). Com a instituição do SMUP, essas 25 áreas serão chamadas de Unidades de Conservação da Natureza (UCN).

\subsection{Recife e as Unidades de Conservação da Natureza em área urbana}

Recife tem uma área territorial de $218,843 \mathrm{~km}^{2}$ e com uma população estimada em 1.645.727 pessoas, seu principal bioma é a Mata Atlântica (IBGE, 2019). As 25 Unidades de Conservação da Natureza (UCN) ocupam quase $40 \%$ de seu território. Tendo em vista a particularidade dessas Unidades de Conservação da Natureza na cidade do Recife estarem localizadas no perímetro urbano, é relevante destacar a lei de criação $n^{0}$ 18.014/2014 do SMUP, que estabeleceu "as normas gerais e requisitos básicos para criação, implantação e gestão das referidas unidades e de suas categorias específicas, dispõe sobre a compensação ambiental" (RECIFE, 2014) no âmbito do município. O SMUP tem como base e é parte integrante do SEUC e do SNUC, mas leva em consideração as peculiaridades das áreas protegidas:

O SMUP Recife é um sistema que agrega os atributos naturais da cidade, abrangendo toda a diversidade de ecossistemas existentes no território municipal,

\footnotetext{
${ }^{15}$ Como Política Pública Ambiental em Pernambuco, é importante destacar a criação da CPRH em 1976, considerando que cresceu "na população os valores ambientais e, por consequência, as exigências pelo controle dos resíduos da indústria, em especial da sucroalcooleira, o Estado autorizou a criação, em 1976, da Companhia Pernambucana de Controle da Poluição Ambiental e de Administração de Recursos Hídricos (CPRH) [...] À Companhia cabiam: o controle de qualidade do meio ambiente - ar, água e solo; o exercício das funções de pesquisas relacionadas ao meio ambiente" entre outros. Informações disponíveis em: http://www.cprh.pe.gov.br/Institucional/historia/41780\%3B69774\%3B4702\%3B0\%3B0.asp. Acesso em 15 Out. 2018.
} 
considerando os grandes maciços vegetais distribuídos nos morros e na planície, conectados pelos cursos e corpos d'água, bem como os espaços inseridos na malha urbana que se apresentam como áreas de amenização climática e compartilhamento socioambiental, bem como de valorização da paisagem urbana, visando à melhoria da qualidade de vida humana (RECIFE, 2014).

As Unidades de Conservação da Natureza estão distribuídas na malha urbana da cidade. A Figura 01 mostra a localização dessas áreas:

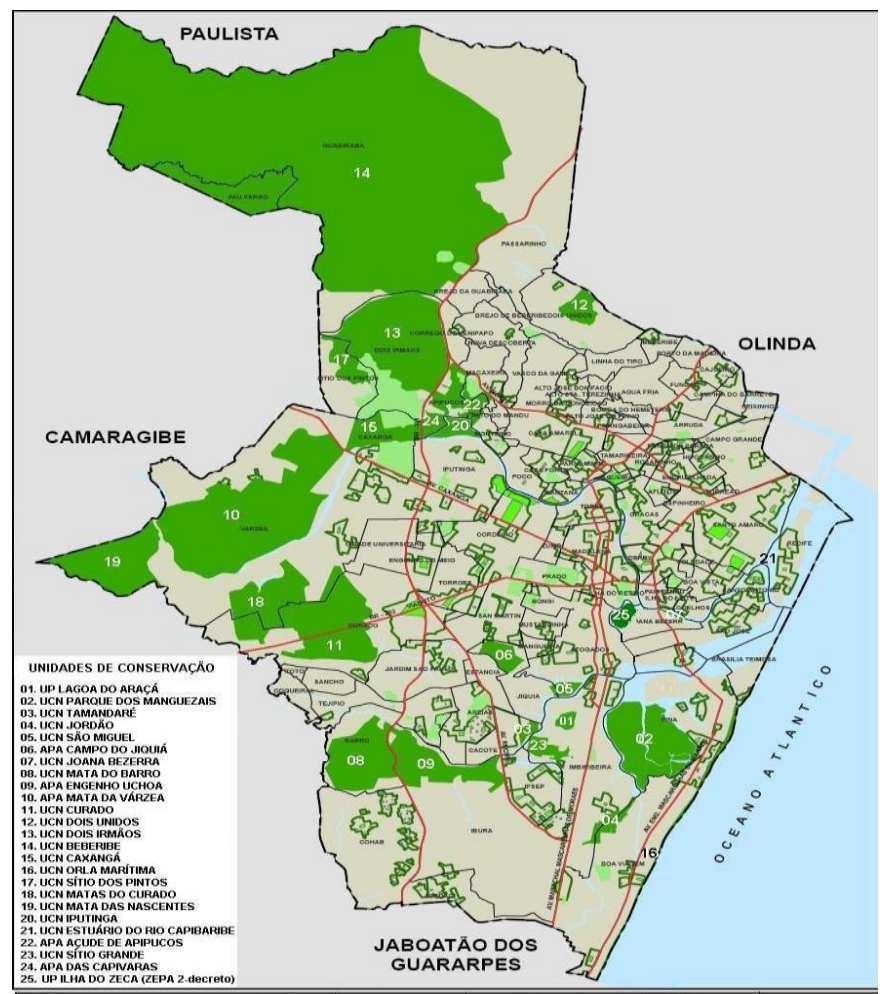

Figura 01 - Localização das Unidades de Conservação Municipais, Recife-PE.

Fonte: PCR. Figura do plano diretor - lei municipal n 17.511/2008.

Cabe acrescentar ainda que, além de integrar os sistemas, Nacional e o Estadual, (SNUC e SEUC), integra a Lei $n^{0}$ 16.243/1996, que é o Código do Meio Ambiente e do Equilíbrio Ecológico da Cidade do Recife. Sobre as Unidades de Conservação da Natureza (UCN), é importante ressaltar a Lei de Uso e Ocupação do Solo (LUOS) no 16. 176/1996"16, que trata da "produção e organização do espaço urbano do Município do Recife, tendo como princípio fundamental a função social da propriedade urbana", sendo necessária a integração sob o ponto de vista das Políticas Públicas entre as áreas urbanas e a natureza.

O SMUP apesar de ser instituído em 2014 e com o prazo de 5 anos para a elaboração de um plano de gestão, chamado de Plano de Manejo dessas UCNs a partir da data de criação do Sistema, a Secretária Municipal de Meio Ambiente do Recife selecionou uma equipe interdisciplinar em 2018 para o cumprimento

\footnotetext{
16 Informações disponíveis em: https://leismunicipais.com.br/plano-de-zoneamento-uso-e-ocupacao-do-solo-recife-pe. Acesso em 22 out. 18.
} 
do que foi determinado segundo as normas vigentes. No entanto, em razão das muitas particularidades de cada UCN e de interferências externas, sejam os interesses dos proprietários de áreas dentro da Unidade, seja por ser área de interseção no SEUC e no SMUP e ainda pelo fato de algumas já terem Planos de Manejo (PM) por parte do Sistema Estadual (a UCN Engenho Uchôa, Aldeia-Beberibe e Parque Dois Irmãos, por exemplo) os PM ainda estão em processo de elaboração por parte do Sistema municipal. Além dessas questões, outras 2 importantes dimensões podem ser consideradas:

O SMUP é uma Política Pública Ambiental no âmbito do município, que nos leva relacioná-la com o conceito de política pública considerado por Muller e Surel (2002), que assim o definiu:

[...] uma toda política governamental se definirá, antes de tudo, como um conjunto de fins a se atingir, como por exemplo "melhorar os rendimentos dos agricultores", "reduzir o desemprego dos jovens", "elevar a capacidade de ataque das forças armadas". Tais fins, ou objetivos, poderão estar mais ou menos explícitos nos textos e nas decisões do governo (o preâmbulo de uma lei, por exemplo), detalhando os objetivos estabelecidos pelo governo no setor em questão (MULLER; SUREL, 2002, p. 16).

É sobre esse prisma que tanto o SMUP quanto os PM's das 25 UCNs são vistos, ou seja, como "um conjunto de fins a se atingir", pois é a partir desses regulamentos que as formas de usos e ocupações dessas áreas serão estabelecidas, especialmente para a população humana local, isto é, Plano de Manejo, que é um [...] "documento técnico mediante o qual, com fundamento nos objetivos gerais de uma unidade de conservação, se estabelece o seu zoneamento e as normas que devem presidir o uso da área e o manejo dos recursos naturais", é previsto ainda para a UCN "a implantação das estruturas físicas necessárias à gestão da unidade" (SMUP, 2014).

Em suma, os dois instrumentos acima mencionados (O SMUP e os PM's) podem ser compreendidos como "um conjunto de medidas concretas" para a proteção dessas áreas, portanto, eles podem ser caracterizados como "outputs reguladores (normativos), financeiros e físicos", medidas concretas que regularizam as formas de uso e ocupação das Unidades de Conservação (MULLER; SUREL, 2002, p. 13, grifos do autor). Dessa maneira é necessário também mencionar que o SMUP Recife "agrega os atributos naturais da cidade, abrangendo toda a diversidade de ecossistemas existentes no território municipal" sem deixar de incluir "os grandes maciços vegetais distribuídos nos morros e na planície, conectados pelos cursos e corpos d’água bem como os espaços inseridos na malha urbana" que são áreas de "amenização climática e compartilhamento socioambiental, bem como de valorização da paisagem urbana, visando a melhoria da qualidade de vida humana" (SMUP, 2014).

O SMUP e os PM's exigidos por esta lei, devido aos problemas destacados, passam por tensões, debates e são alvos de disputas entre os sujeitos presentes as reuniões (comunidades locais, grupos 
empresariais, Estado), mostrando os embates aí presentes (LIMA, 2018), que o conformam como um campo de lutas, um campo político, que se traduzirá no perfil das ações públicas que são (e serão) implementadas.

Nesse escopo, a Prefeitura da Cidade do Recife (PCR) através da Secretaria de Desenvolvimento Sustentável e Meio Ambiente (SDSMA), considera como principal instrumento da Política Ambiental Municipal o disposto Capítulo IV do Plano Diretor do Recife (Lei Municipal n 17.511/200817), que pode ser interpretada como:

[...] conjunto de diretrizes, instrumentos e mecanismos de política pública que orienta a gestão municipal na perspectiva de fomentar o desenvolvimento sustentável, alicerçado na justiça social, no crescimento econômico e no equilíbrio ambiental, promovendo melhorias na qualidade de vida da população. São instrumentos para a gestão ambiental, dentre outros, o Conselho Municipal do Meio Ambiente, o Fundo Municipal do Meio Ambiente, a Brigada Ambiental, o Zoneamento Ambiental, o Sistema Municipal de Unidades Protegidas (SMUP) do Recife, o Licenciamento Ambiental, a Fiscalização Ambiental e a Compensação Ambiental.

Mas sob o ponto de vista da história da Política Ambiental do Município, anteriormente ao SMUP, outro importante passo na Política Ambiental em Recife, especialmente quanto à criação das UCNs foi a instituição da Lei Municipal № 16.176/96 - Lei de Uso e Ocupação do Solo (LUOS), que entre suas diretrizes estabeleceu as Zonas Especiais de Proteção Ambiental (ZEPA), que definiu: $1^{0}$ ) "Zona Especial de Proteção Ambiental 1 - ZEPA 1, constituída por todas as áreas verdes públicas, inclusive aquelas áreas destinadas à recreação e lazer de uso comum e outras previstas em Lei"; e $2^{0}$ - "Zona Especial de Proteção Ambiental 2 ZEPA 2, constituída por áreas públicas ou privadas com características excepcionais de matas, mangues, açudes e cursos d’água" (RECIFE, 2014). Nesses termos, a Lei definiu o conceito de ZEPA:

[...] áreas de interesse ambiental e paisagístico necessárias à preservação das condições de amenização do ambiente e aquelas destinadas a atividades esportivas ou recreativas de uso público, bem como as áreas que apresentam características excepcionais de matas, mangues e açudes (LUOS, 1996).

Foi dentro desse contexto que foram incluídas 21 Unidades de Conservação da Natureza de Recife. As outras 4 UCNs foram instituídas posteriormente à LUOS e que também são resultados de Leis Municipais, que são elas: a UCN Açude de Apipucos criada por intermédio da Lei 16.609/2000, a UCN Sítio Grande através da Lei 16.751/2002; a APA ${ }^{18}$ das Capivaras através da Lei 16.719/2001 e a mais recente é a ARIE ${ }^{19}$ Ilha do Zeca, criada por meio da Lei 16.869/2003. Há ainda mais 3 Unidades de Conservação da Natureza, mas que são regulamentas por outros instrumentos jurídicos: Parque da Jaqueira, Parque Tamarineira e 0 Jardim Botânico do Recife. Nessa perspectiva é importante trazer a definição de Unidade de Conservação da Natureza sob o ponto de vista do SMUP (2014):

\footnotetext{
17 Atualmente a PCR encontra-se em processo de elaboração do Plano de Diretor da Cidade.

18 Área de Proteção Ambiental.

19 Área de Relevante Interesse Ecológico.
} 
As Unidades de Conservação da Natureza (UCN) são espaços territoriais e seus recursos ambientais, incluindo as águas jurisdicionais, com características naturais relevantes, instituídos pelo Poder Público, com objetivos de conservação e limites definidos, sob regime especial de administração, ao qual se aplicam garantias adequadas de proteção.

O Quadro 2 reúne as 25 UCNs de Recife, bem como sua localização:

Quadro 02 - Nomes das UCNS, lei de criação, decretos e bairro da unidade na cidade de Recife-PE

\begin{tabular}{|c|c|c|c|}
\hline DENOMINAÇÃO & $\begin{array}{l}\text { N}^{0} \text { LEI DE } \\
\text { CRIAÇÃOO }\end{array}$ & $\begin{array}{r}\text { DECRETO } \\
\text { MUNICIPAL }\end{array}$ & BAIRRO \\
\hline UCN Lagoa do Araçá & 16.176/96(LUOS $\left.{ }^{20}\right)$ & $18.029 / 98$ & Imbiribeira \\
\hline $\begin{array}{c}\text { Parque Natural Municipal dos } \\
\text { Manguezais }\end{array}$ & $16.176 / 96$ & $25.565 / 2010$ & Pina \\
\hline UCN Tamandaré & $16.176 / 96$ & $23.820 / 08$ & Areias \\
\hline UCN Jordão & $16.176 / 96$ & $23.812 / 08$ & $\begin{array}{c}\text { Imbiribeira / Boa } \\
\text { Viagem }\end{array}$ \\
\hline UCN São Miguel & $16.176 / 96$ & $23.817 / 08$ & Afogados \\
\hline APA Campo do Jiquiá & $16.176 / 96$ & $21.828 / 06$ & Jiquiá \\
\hline UCN Joana Bezerra & $16.176 / 96$ & $23.811 / 08$ & Joana Bezerra \\
\hline UCN Mata do Barro & $16.176 / 96$ & $23.813 / 08$ & Barro \\
\hline $\begin{array}{c}\text { APA Mata do Engenho Uchôa (abriga o } \\
\text { RVS) }\end{array}$ & $16.176 / 96$ & $17.548 / 96$ & Ibura \\
\hline APA Mata da Várzea & $16.176 / 96$ & $22.154 / 06$ & Várzea \\
\hline $\begin{array}{c}\text { UCN Curado (abriga o Jardim Botânico } \\
\text { do Recife e parte do RVS }{ }^{21} \text { Mata do } \\
\text { Curado) }\end{array}$ & $16.176 / 96$ & $23.806 / 08$ & Curado \\
\hline UCN Dois Unidos Mata de Dois Unidos) & $16.176 / 96$ & $23.808 / 08$ & Dois Unidos \\
\hline $\begin{array}{l}\text { UCN Dois Irmãos (abriga o Parque } \\
\text { Estadual de Dois Irmãos) }\end{array}$ & $16.176 / 96$ & $23.807 / 08$ & Dois Irmãos \\
\hline UCN Beberibe & $16.176 / 96$ & $23.804 / 08$ & Guabiraba \\
\hline UCN Caxangá & $16.176 / 96$ & $23.805 / 08$ & Caxangá \\
\hline UCN Orla Marítima & $16.176 / 96$ & $23.816 / 08$ & Pina, Boa Viagem \\
\hline UCN Sítio dos Pintos & $16.176 / 96$ & $23.818 / 08$ & Sítio dos Pintos \\
\hline UCN Matas do Curado & $16.176 / 96$ & $23.815 / 08$ & Curado \\
\hline UCN Mata das Nascentes & $16.176 / 96$ & $23.814 / 08$ & Várzea \\
\hline UCN Iputinga & $16.176 / 96$ & $23.810 / 08$ & Apipucos \\
\hline UCN Estuário do Rio Capibaribe22 & $16.176 / 96$ & $23.809 / 08$ & - \\
\hline APA Açude de Apipucos & $16.609 / 00$ & $22.460 / 06$ & Apipucos \\
\hline UCN Sítio Grande & $16.751 / 02$ & $23.819 / 08$ & Imbiribeira \\
\hline APA das Capivaras & $16.719 / 01$ & $22.326 / 06$ & Apipucos \\
\hline ARIE Ilha do Zeca & $16.869 / 03$ & $23.825 / 08$ & Ilha Joana Bezerra \\
\hline
\end{tabular}

Fonte: Secretaria de Meio Ambiente e Sustentabilidade (SMAS) do Recife (adaptada pelos autores).

20 Lei de Uso e Ocupação do Solo.

21 Refúgio da Vida Silvestre.

22 Essa UCN atravessa o total de 24 bairros na cidade do Recife. 
Das 25 Unidades, 7 já estão categorizadas, mas em conformidade com o SMUP, essas passarão por análise e poderão ter sua categoria modificada: Parque Natural Municipal dos Manguezais, APA Campo do Jiquiá, APA Mata do Engenho Uchôa (abriga o RVS), APA Mata da Várzea, APA Açude de Apipucos, APA das Capivaras e Arie Ilha do Zeca. Do total de UCNs, 3 dispõem de Plano de Manejo (PM) pelo Governo do Estado (Secretaria Estadual de Meio Ambiente - SEMAS), são elas: APA Mata do Engenho Uchôa: Refúgio de Vida Silvestre (RVS) em 2013, Parque Estadual Dois Irmãos (PEDI) inserido na Unidade de Conservação de Dois Irmãos e a APA Aldeia-Beberibe ambos publicados em 2012. A Política inserida dentro do SMUP é, portanto, resultado de uma pressão interna e também externa, segue regras universais, mas traz à tona as particularidades das UCNs localizadas em Recife (em especial) o fato de que a maioria das áreas protegidas ser habitada. Portanto, toda e qualquer decisão deve levar em consideração essa realidade social, suas tensões, histórias e condições de existência socioambiental, o que coloca um peso relevante para o pensar e o fazer desta política pública.

\section{Pressão populacional como resultado da ausência de Política Públicas Sociais}

As 25 UCNs estão inseridas no perímetro urbano em Recife, ocupando quase $40 \%$ da cidade. Essa é uma particularidade relevante para essas Unidades, especialmente por conta da pressão populacional, que na maioria dos casos, estão dentro ou no entorno das áreas protegidas (caracterizado por vegetação, das águas e dos retalhos verdes do espaço urbano), que descortina um antigo problema, comum aos centros urbanos, que é a falta de política de habitação, reverberando em outros problemas de cunho sociais e que são históricas em Recife: situação socioeconômica das comunidades (desigualdade e vulnerabilidade sociais, desemprego, baixa escolaridade, entre outros) que leva as pessoas a morarem em lugares precários, sem saneamento básico, suscetível a doenças oriundas da poluição da água, por exemplo.

Desde a LUOS (1996), essa questão entrou na pauta da política ambiental no estado, tendo em vista a criação das Zonas Especiais de Interesse Social, as ZEIS, distribuídas nas 6 Regiões Político Administrativa (RPA), formadas pelos bairros da cidade. As ZEIS "são áreas de assentamentos habitacionais de população de baixa renda, surgidos espontaneamente, existentes, consolidados ou propostos pelo Poder Público, onde haja possibilidade de urbanização e regularização fundiária". Mas, a busca por moradia é crescente, o que justifica a criação das Comunidades de Interesse Social, as CIS, que hoje são mais numerosas do que as ZEIS, que até 2014 somavam 66; já as CIS passam de 500 (FERREIRA, 2019). Com a definição do novo Plano Diretor da Cidade em 2018, apenas 53 CIS foram categorizadas como ZEIS (. Sobre as CIS é fundamental dizer que são ocupações informais mais recentes, surgidas depois da definição das ZEIS. Outra questão crucial é que as CIS estão entremeadas com as UCNs de Recife e são um reflexo da 
falta de política pública habitacional por parte da gestão municipal e a profunda e histórica desigualdade existente na cidade, já retratada há décadas por Josué de Castro em seu clássico livro Homens e Caranguejos (CASTRO, 1967), anunciando os desafios e as particularidades socioambientais que definem a capital pernambucana.

Sobre o SMUP, é pertinente salientar que ele se encontra dentro de uma tendência nacional voltada para a criação do Sistema Municipal de Unidades de Conservação (SMUC), ou seja, a institucionalização por parte dos municípios de um Sistema para as áreas protegidas locais (SOS MATA ATLÂNTICA, 2017). 0 Sistema definiu o Plano de Manejo com base no SNUC, isto é, como um "documento técnico mediante o qual, com fundamento nos objetivos gerais de uma unidade de conservação, se estabelece o seu zoneamento e as normas que devem presidir o uso da área e o manejo dos recursos naturais" (SMUP, 2014).

A Secretaria de Meio Ambiente e Sustentabilidade (SMAS) da Prefeitura da Cidade do Recife (PCR) ficou responsável pela elaboração dos Planos de Manejo das 25 UCNs previstos no SMUP desde a sua publicação em 2014, que tem prazo até maio de 2019 para sua efetivação, no período de 2018 a 201923 . A forma estabelecida pela SMAS foi a realização da Mobilização Social para as Oficinas Participativas do Diagnóstico Socioambiental para todas as Unidades (e também para as demais etapas do processo: zoneamento e programas) no período de junho a agosto de 2018, com tensões marcantes entre os sujeitos presentes na mesma (LIMA, 2018). O Diagnóstico foi a primeira etapa para elaboração do Plano de Manejo, que é um documento descritivo e analítico das potencialidades do Meio Biótico. Composto pelos aspectos físicos e biológicos e meio antrópico (dados populacionais e aspectos socioeconômicos e urbanísticos) e ao uso e ocupação do solo que corresponde à área da UCN, bairro e entorno.

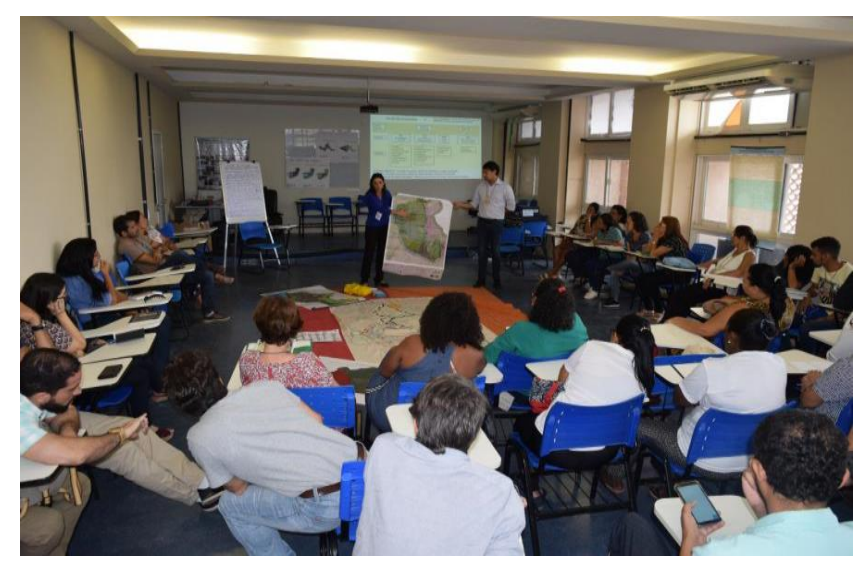

Figura 02 - Oficina Participativa de Zoneamento e Programas

Fonte: SMAS/PCR - Oficina Participativa de Zoneamento e Programas de Manejo das UCNs Mata da Várzea e Mata das Nascentes, Recife-PE.

\footnotetext{
${ }^{23}$ Em razão de mudanças políticas e administrativas na Prefeitura em 2020 parte das atividades vinculadas ao Meio Ambiente, a exemplo dos Planos de Manejos, passaram a ser vinculadas à Secretaria de Mobilidade e Controle Urbano.
} 
A categorização foi a partir do levantamento/conhecimento biótico e social prévio da equipe da Secretaria. O zoneamento e o programa também foram realizados através das Oficinas participativas, iniciando em outubro de 2018. Quanto aos programas, estes foram e serão direcionados para diversas finalidades como: educação ambiental, fiscalização, patrimônio histórico e cultural, ecoturismo, pesquisa, recuperação ambiental, interação socioambiental, produção técnica e científica, desenvolvimento sustentável, monitoramento, entre outros, que dependerão do atributo natural (corpo d'água, mata, mangue, etc) de cada UCN24 e também da necessidade da população local. Todas essas ações compõem as particularidades da questão ambiental que se apresentam em Recife traduzidas no SMUP e na busca pela implantação de seus Planos de Manejo enquanto políticas públicas, que, se por um lado, colhe as influências das normas internacionais e nacionais, por outro, expressa limites, desigualdades, concepções, lutas e demandas históricas em relação à questão socioambiental em Recife, o que explicita as lutas presentes neste campo político.

\section{CONSIDERAÇÕES FINAIS}

Para fins analíticos, o SMUP é considerado a principal política ambiental da cidade de Recife e resultado de ações nacionais de proteção da natureza, a partir do SNUC e estadual em razão do SEUC. Todas elas não deixaram de alimentar-se dos debates e encaminhamentos internacionais oriundos dos diversos encontros e suas decisões estabelecidas pela ONU. Apesar de alimentar-se dessas influências e condicionantes nacionais e globais, o SMUP ganhou conformação de acordo com a realidade vivida em Recife. Por exemplo, ele transformou todas as Zonas Especiais de Proteção Ambiental (ZEPA) no âmbito da LUOS de 1996 em UCNs e tem que lidar com as profundas desigualdades sociais presentes em Recife, bem como as especificidades de cada ambiente e suas pressões socioeconômicas. Assim, a importância de discutir as iniciativas do SMUP é o fato de estarem inseridas no âmbito do debate ambiental, além de associadas a um conjunto de questões sociais, econômicas, políticas e históricas no plano local, seus dramas e configurações que assumem a partir de cada bairro. Ou seja, além da existência das Comunidades de Interesse Social, as CIS, tem áreas privadas e com um grupo social de alto poder aquisitivo, como é o caso da Mata da Várzea que tem como proprietária a família Brennand. Outra área bastante adensada e representada pela desigualdade social é a UCN Sítio dos Pintos em razão dos muitos condomínios de luxo e ocupações urbanas dentro do traçado da UCN. A UCN APA Campo do Jiquiá tem um importante valor histórico por abrigar em sua área a torre utilizada no período de 1930 a 1937 pelo Graff Zeppelin, um dirigível de origem alemã, que ligou a Europa à América do Sul, denominado "Aeroporto do Jiquiá". Além disso, abriga

\footnotetext{
${ }^{24}$ Até a presente data (abril/2020) os Planos de Manejos não foram concluídos em sua totalidade, UCNs como Estuário Capibaribe e Orla Marítima são exemplos.
} 
6 comunidades no entorno da UCN: Favelinha, Zeppelin (inserida no bairro da UCN), Portelinha, Cabeça de Vaca, Caxito e Vila Tenente. Assim, cada UCN tem suas particularidades ecológicas e necessidades sociais que devem ser consideradas e incorporadas nos Planos de Manejo.

O SMUP foi elaborado a fim de proteger os fragmentos florestais frente à ideia de conservação urbana, sem desconsiderar alguns aspectos relevantes: o movimento de luta por moradia na capital da cidade datada de 1916 até os dias atuais, as ocupações que tornam-se moradias precárias, especialmente nas áreas das Unidades de Conservação da Natureza, que por sua vez revelam diversos problemas de natureza social: falta de política de habitação; falta de saneamento básico, incluído a péssima qualidade da água; desemprego; situação de vulnerabilidade e exclusão social (considerando nesse item a violência urbana, falta de segurança e o tráfico de drogas); a especulação imobiliária é outra questão que interfere fortemente nas UCNs, pois muitas delas são alvo de grande interesse das construtoras por seus atributos naturais, refletindo as desigualdade sociais, especialmente a econômica. Sem dúvida, o SMUP expressa um rico campo político, cuja questão ambiental é o centro que se ilumina a partir de demandas locais (oriundas de diversos sujeitos sociais) e dos debates, normas e leis nacionais e internacionais, para que pudesse constituir-se e efetivar-se enquanto uma política pública ambiental na capital pernambucana.

\section{REFERÊNCIAS}

BOURDIEU, Pierre. O campo político. Revista Brasileira de Ciência Política. Brasília, n.5, 2011.

0 poder simbólico. $7^{\text {a }}$ Ed., Rio de Janeiro, Bertrand Brasil, 2004.

BRASIL. Sistema Nacional de Unidades de Conservação da Natureza - SNUC, lei n ${ }^{\circ} 9.985$, de 18 de julho de 2000; decreto $n^{0} 4.340$, de 22 de agosto de 2002. $7^{a}$ edição. Brasília, 2007.

NEGREIROS, Emílio de Britto. Os conflitos ambientais na Estação Ecológica de Caetés-PE. Estudos de Sociologia (UFPE), v. 2, 2018.

. Natureza Mínima - Política Ambiental e Unidades de Conservação em Pernambuco: um estudo sobre a Estação Ecológica de Caetés e a Área de Proteção Ambiental do Engenho Uchoa. (Tese de Doutorado em Sociologia). Recife, UFPE, 2008.

BURSZTYN, Maria Augusta; BURSZTYN, Marcel. Fundamentos de política e gestão ambiental: caminhos para a sustentabilidade. Rio de Janeiro, Garamond, 2013.

CARREGOSA, Elenice Almeida; SILVA, Sandra Lúcia da Cunha e; KUNHAVALIK, José Pedro. Unidade de Conservação e comunidade local: uma relação em construção. Revista Desenvolvimento e Meio Ambiente. Vol. 35, 2015.

CASTRO, Josué de. Homens e caranguejos. São Paulo: Brasiliense, 1967.

DIEGUES, Antonio Carlos (org.) Comunidades Tradicionais e Manejo dos Recursos Naturais da Mata Atlântica. $2^{\mathrm{a}}$ edição - São Paulo: Hucitec: NUPAUBUSP: CEC, 2004.

FERREIRA, Demetrius Rofrigues de Freitas. Uma nova agenda para o saneamento: estratégias, interesses e racionalidades na formulação da parceria públicoprivada de esgoto do Recife. (Tese de Doutorado em Sociologia). Recife, UFPE, 2019.

IPIRANGA, Ana Silvia Rocha; GODOY, Arilda Schmidt; BRUNSTEIN, Janette. Introdução. RAM, Rev. Adm. Mackenzie (Online), São Paulo, v. 12, n. 3, 2011.

LIMA, Renata Karine Viana de. As configurações socioambientais na Cidade do Recife-PE: o caso das oficinas participativas para o diagnóstico das unidades de conservação ambiental e realização de seus planos de manejo. (Monografia em Ciências Ambientais). Recife, UFPE, 2018. 
MORAIS, João Rafael Gomes de. FETAPE, ações coletivas e natureza: a questão do bioma caatinga de clima semiárido em Pernambuco. (Dissertação de Mestrado em Sociologia). Recife, UFPE, 2020.

MOREIRA, Helena Margarido; GIOMETTI, Analúcia Bueno dos Reis. O Protocolo de Quioto e as possibilidades de inserção do Brasil no mecanismo de desenvolvimento limpo por meio de projetos em energia limpa. Contexto Internacional. vol. 30 , no 1. Rio de Janeiro, 2008.

MULLER, Peter; SUREL, Yves. Análise das Políticas Públicas. Pelotas, RS, Educat, 2002.

NASCIMENTO, Elimar Pinheiro do. Trajetória da sustentabilidade: do ambiental ao social, do social ao econômico. Estudos Avançados. Vol.26, n 74, São Paulo, 2012

RAMALHO, Cristiano Wellington Noberto; SANTOS, Andreia Patrícia dos. Por mares revoltos: a mediação política do Conselho Pastoral dos Pescadores (19682018). In: Revista de Economia e Sociologia Rural, Brasilia, vol.58, n.1, p. 74-92, 2020

RECIFE. Lei no 9.931, de 11 de dezembro de 1986. Proteção de Áreas Estuarinas, Recife, PE, dez 1986. Disponivel em:

http://legis.alepe.pe.gov.br/texto.aspx?id=4853\&tipo=T EXTOORIGINAL. Acesso em 22 jan. 2019.

RECIFE. Lei no 9.960 de 17 de dezembro de 1986.

Proteção da Orla Marítima, Recife, PE, dez 1986.

Disponivel em:

http://legis.alepe.pe.gov.br/texto.aspx?id=4853\&tipo=T EXTOORIGINAL. Acesso em 22 jan. 2019.

RECIFE. Lei no 9.989 de 13 de janeiro de 1987.

Reservas Ecológicas na Região, Recife, PE, dez 1986. Disponivel em:

http://legis.alepe.pe.gov.br/texto.aspx?id=4853\&tipo=T EXTOORIGINAL. Acesso em 22 jan. 2019.

RECIFE. Lei Municipal N $N^{0} 16.176$ de 13 de abril de 1996. Lei de Uso e Ocupação do Solo (LUOS). Recife, PE, abr 1996. Disponível em:

https://leismunicipais.com.br/a1/plano-de-zoneamentouso-e-ocupacao-do-solo-recife-pe. Acesso em 22 out. 2018.

RECIFE. Lei Municipal NN 18.014 de 09 de maio de 2014. Sistema Municipal de Unidades Protegidas.

Recife, PE, mai 2014. Disponível em: https://leismunicipais.com.br/a1/pe/r/recife/leiordinaria/2014/1801/18014/lei-ordinaria-n-18014-2014institui-o-sistema-municipal-de-unidades-protegidassmup-recife-e-da-outras-providencias. Acesso em 02 abr. 2018.

SANTOS, Andreia Patricia dos. Fomento à Pesquisa em Meio Ambiente: o CNPq e as Faps da Região
Nordeste do Brasil (2005-2015). (Tese de Doutorado em Desenvolvimento e Meio Ambiente), São Cristóvão/SE, UFS, 2017.

SEQUINEL, Maria Carmen Mattana. Cúpula mundial sobre desenvolvimento sustentável - Joanesburgo: entre o sonho e o possível. Análise Conjuntural, v.24, Paraná. 2002

SILVA, Darly Henriques da. Protocolos de Montreal e Kyoto: pontos em comum e diferenças fundamentais. Rev. bras. polít. int. vol.52, n², 2009.

TILIO NETO, Petrônio De. Ecopolítica das mudanças climáticas: o IPCC e o ecologismo dos pobres. Rio de Janeiro: Centro Edelstein de Pesquisas Sociais, 2010. 